Mini review

\title{
Recent advancements in nanomaterials-based electrochemiluminescent and photoelectrochemical techniques for the determination of beta-amyloid peptides
}

\author{
Yunxiao Feng ${ }^{*}$ and Ming La*
}

College of Chemistry and Chemical Engineering, Pingdingshan University, Pingdingshan, Henan 467000, People's Republic of China

*E-mail: 2743@pdsu.edu.cn (Y.F.); mingla2011@163.com (M.L.)

Received: 2 December 2021 / Accepted: 19 December 2021 / Published: 5 January 2022

Beta-amyloid $(\mathrm{A} \beta)$ peptides have been considered as the core biomarkers for early diagnosis of Alzheimer's disease. Electrochemiluminescent (ECL) and photoelectrochemical (PEC) biosensors are two promising methods for disease diagnosis in view of their merits of high sensitivity, low-cost and broad dynamic response range. In this review, we summarized the development of ECL and PEC biosensors for the sensitive analysis of $\mathrm{A} \beta$ species.

Keywords: electrochemiluminescence; photoelectrochemistry; nanomaterials; Alzheimer's disease; beta-amyloid peptides

\section{$\underline{\text { FULL TEXT }}$}

(C) 2022 The Authors. Published by ESG (www.electrochemsci.org). This article is an open access article distributed under the terms and conditions of the Creative Commons Attribution license (http://creativecommons.org/licenses/by/4.0/). 